\title{
Chapter 7 \\ Restrictions on Access to Social Protection \\ by New Southern European Migrants \\ in Belgium
}

\author{
Jean-Michel Lafleur and Mikolaj Stanek
}

\subsection{Introduction}

Since the post-war period, immigration into Belgium has passed through several stages: an influx of guest workers (predominately from Southern Europe), the closure of migrant recruitment programmes and subsequent intensification of family reunification, asylum seeking, and increased numbers of arrivals of EU migrants. Although recent flows have seen a predominance of Central and Eastern European migrants, Southern European migration to Belgium has also gradually increased. Forty years after the end of the guest worker programmes, old migration routes to Belgium thus seem to be reopening.

The context in which Southern European migration is occurring today is, however, significantly different. Belgium is not the Member State that has received the largest numbers of EU migrants in recent years, and nor has it suffered the most from the economic crisis. Nevertheless, public support towards new EU migration has greatly decreased over the years (Freedman 2012). In particular, fears over the competition between native and foreign workers and concerns about the impact of the latter on the welfare system have become particularly salient.

Suspicion towards Southern European migration is a new phenomenon in Belgium. Indeed, following the guest worker era, the successful socio-economic and political integration of Southern European migrants had progressively turned them into the ideal-type of migrants in Belgian public debates. As we will show, this idealization process served mainly to delegitimize the presence of the third country

\footnotetext{
J.-M. Lafleur (西)

FRS-FRNS, Centre for Ethnic and Migration Studies (CEDEM), University of Liège,

Liège, Belgium

e-mail: jm.lafleur@ulg.ac.be

M. Stanek

Department of Sociology and Communication, University of Salamanca, Salamanca, Spain

e-mail: mstanek@usal.es
} 
migrants who arrived after them. Newcomers from Southern Europe, however, no longer benefit from the positive image associated with their predecessors. In policy terms, this change of attitude has materialized in new measures aiming at keeping undesirable EU migrants out. The most controversial of these measures consists of the removal of residence permits from unemployed EU citizens considered to represent an unreasonable burden on the Belgian public finances. Although migrants from Central and Eastern EU countries have been the most affected, a considerable number of nationals from North-Western and Southern EU countries have also been expelled.

The overall objective of this chapter is therefore to analyse how social policies have progressively become instruments of migration control in Belgium within the context of the economic crisis. First, we briefly discuss the recent economic and social situation, and explore the impacts of the economic downturn on the Belgian welfare system. We then describe past and recent migration flows to the country and discuss the main socio-demographic features of foreign residents from Southern Europe and other EU regions. We also highlight the socio-economic situation of Southern European migrants in terms of activity and unemployment rates, and of access to selected welfare benefits. In the second part of the chapter, we demonstrate how the process of idealization of Southern European immigration has taken place in Belgium. This process has resulted in an implicit classification between undesirable and desirable migrants. Accordingly, stricter immigration and integration policies are designed to keep the former out while still appearing attractive to the latter. We then focus on the specific policy of removing residence permits, targeting EU jobseekers during the economic crisis. We analyse the effects of this policy and, in the process, show that Belgium's strict welfare provisions not only limit the free mobility of workers in times of crisis but also stigmatize new EU migrants as "welfare shoppers". On examining the mobilization of different organizations, we conclude by showing that — while they are numerically fewer-new Southern European immigrants are in a better position than other new immigrants to challenge policies that affect their freedom of circulation.

\subsection{European Migration to Belgium: Present Meets Past}

\subsubsection{The Social and Economic Situation in Belgium in the Context of the Recent Global Crisis}

Similarly to the vast majority of EU Member States, Belgium was hit by the economic crisis in the late 2000s. In its initial phase (2008-2009), the turmoil mainly affected the financial sector, as Belgian banks faced liquidity and solvency problems. However, the economic and social setback of the financial system was further aggravated by a political crisis following the 2007 federal election, which left the country without a government for several months (Rihoux et al. 2011). Two 
indicators illustrate Belgium's difficulties at the time. First, the general government deficit rose from $-1.3 \%$ of GDP in 2008 to $-6.0 \%$ of GDP in 2009. Second, public debt increased from $89.6 \%$ of GDP in 2008 to $96.2 \%$ in 2009. In this period, Belgium was considered to be at high risk of falling into a long lasting and profound economic crisis along with other Member States such as Portugal, Spain, Ireland, Greece and Italy.

Even though in the years that followed, Belgium began to gradually recover from the initially dramatic turmoil, its economic performance remained fragile and mostly unstable (OECD 2015). As shown in Table 7.1, the basic indicators of the Belgian economy have shown a fluctuating pattern, with recovery in 2010 and 2011 and, again, a slight decline in the following 2 years. Overall, Belgium seems to have performed just slightly better than the EU and the Eurozone average, as illustrated by the fact that the Purchasing Power Parity adjusted Gross Domestic Product per capita has remained $20 \%$ above the average EU level throughout the economic crisis.

The financial turmoil in 2008 and 2009 has had negative consequences on the labour market in Belgium. Between 2008 and 2009, there was a net loss of 20,000 jobs, or a net drop of $1.2 \%$ (see Table 7.2). During the following 4 years (2010-

Table 7.1 Evolution of GDP indicators in Belgium and the EU-27

\begin{tabular}{l|l|l|l}
\hline & $\begin{array}{l}\text { GDP per inhabitant as a \% of EU } \\
\text { average: Belgium }\end{array}$ & $\begin{array}{l}\text { GDP growth rate: } \\
\text { EU-27 }\end{array}$ & $\begin{array}{l}\text { GDP growth rate: } \\
\text { Belgium }\end{array}$ \\
\hline 2003 & $124 \%$ & 1.5 & 0.8 \\
\hline 2004 & $121 \%$ & 2.5 & 3.6 \\
\hline 2005 & $120 \%$ & 2.0 & 2.1 \\
\hline 2006 & $118 \%$ & 3.4 & 2.5 \\
\hline 2007 & $116 \%$ & 3.1 & 3.4 \\
\hline 2008 & $116 \%$ & 0.5 & 0.7 \\
\hline 2009 & $118 \%$ & -4.4 & -2.3 \\
\hline 2010 & $120 \%$ & 2.1 & 2.7 \\
\hline 2011 & $120 \%$ & 1.7 & 1.8 \\
\hline 2012 & $120 \%$ & -0.5 & 0.2 \\
\hline 2013 & $119 \%$ & 0.2 & 0.0 \\
\hline 2014 & $119 \%$ & 1.4 & 1.3 \\
\hline
\end{tabular}

Sources: EU Labour Force Survey 2005-2013

Table 7.2 Evolution of unemployment rates in Belgium and the EU-27 2005-2013

\begin{tabular}{l|l|l|l|l|l|l|l|l|l}
\hline Unemployment rate & 2006 & 2007 & 2008 & 2009 & 2010 & 2011 & 2012 & 2013 & 2014 \\
\hline Belgium - total & 8.3 & 7.5 & 7.0 & 7.9 & 8.3 & 7.2 & 7.6 & 8.4 & 8.5 \\
\hline Belgium - long term & 4.2 & 3.8 & 3.3 & 3.5 & 4.1 & 3.5 & 3.4 & 3.9 & 4.3 \\
\hline Belgium - men & 7.4 & 6.7 & 6.5 & 7.8 & 8.1 & 7.1. & 7.7 & 8.7 & 9.0 \\
\hline Belgium - women & 9.3 & 8.5 & 7.6 & 8.1 & 8.5 & 7.2 & 7.4 & 8.2 & 7.9 \\
\hline EU-27 & 8.2 & 7.2 & 7,0 & 8.9 & 9.6 & 9.6 & 10.4 & 10.8 & 10.2 \\
\hline
\end{tabular}

Sources: Eurostat (EU Labour Force Survey), Algemene Directie Statistiek EAK 


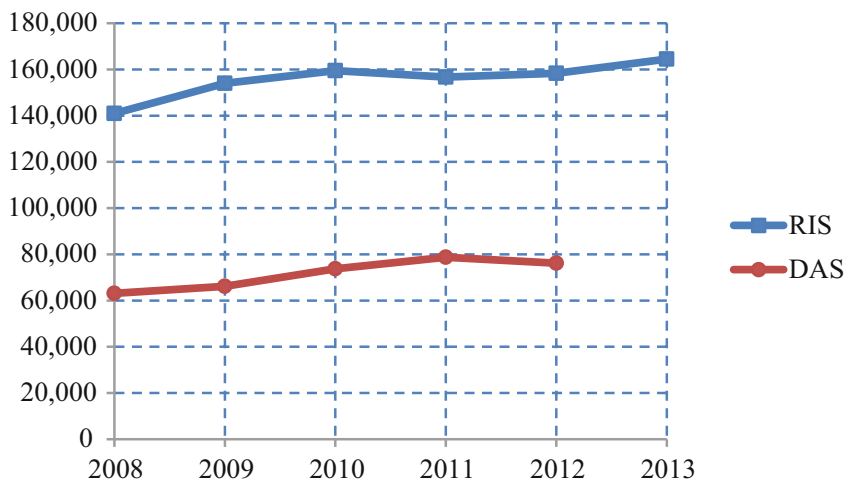

Fig. 7.1 Evolution of absolute numbers within the social integration income (RIS) and right to social aid (DAS) schemes (Source: Intégration Sociale 2013)

2014), variations in unemployment levels continued to reflect the volatile socioeconomic environment (De Mulder and Druant 2011). Yet, long-term unemployment remained relatively stable throughout this period, which confirms the conjectural nature of these fluctuations.

Belgium's approach to protecting employment during the crisis has consisted of keeping a fragile balance between activation policies undertaken on the federal and regional level, on the one hand, and austerity measures imposed by the European Commission on the other hand (Høj 2013). Activation measures have consisted mostly of implementing reduced working hours and temporary unemployment schemes to encourage employers not to terminate contracts (Hijzen and Venn 2011). Other measures have included the reduction of wage costs for certain categories of workers, full or partial exemption from social security contributions, and further training and job search assistance (Starke et al. 2011).

However, the economic slowdown and the instability of the labour market have resulted in the deterioration of living conditions and increasing inequalities in the country. This, in turn, has exerted a considerable stress on the non-contributory social assistance system. As shown in Fig. 7.1, between 2008 and 2013, the number of beneficiaries of the social integration income scheme (Revenu d'Intégration Sociale, hereafter $\mathrm{RIS}^{2}$ ) incremented by almost $14 \%$ per year (from approximately

\footnotetext{
${ }^{1}$ In addition to active employment policies implemented before and during the crisis, other contextual factors have mitigated the impact of the crisis. In this respect, we can mention the diversified nature of the Belgian economy and the relatively high proportion of public jobs (especially in Wallonia).

${ }^{2}$ The social integration income scheme (RIS) provides a non-contributory minimum income for people with no sufficient resources, who are unable to obtain them by their own efforts. Recipients are usually required to demonstrate the willingness to work, unless this is impossible for health or equity reasons. EU citizens who have a residence permit of more than 3 months in Belgium are eligible for RIS.
} 
141,000 to over 164,000). On the other hand, the number of individuals who qualified for the right to social aid sub-scheme (Droit à l'Aide Sociale, hereafter $\mathrm{DAS}^{3}$ ) incremented by almost $17 \%$, from approximately 63,000 in 2008 to 76,200 in 2013 (Intégration Sociale 2013).

The growing need for social assistance in times of crisis, however, has collided with the austerity measures imposed by both EU and Belgian federal policies. To meet the targets of the budget deficit reduction plans, employment activation and welfare policy expenditure have been accompanied by tax increases and cuts in public spending in areas such as health care, education and pension schemes (Castanheira et al. 2014; Pignal 2012). In addition, more stringent controls and the supervision of beneficiaries of social assistance have been introduced with the stated objective of reducing fraud and misuse of benefits (Nelson 2011). As we shall see in detail below, several of these restrictive measures have specifically targeted the immigrant population.

\subsubsection{Migration to Belgium: Historical Overview}

Belgium's migration history is profoundly shaped by its industrial history. During the nineteenth century and the progressive industrialization of the country, Belgium attracted a growing number of foreign workers, mostly from neighbouring countries. This phenomenon intensified after World War I, which, in addition to migration from those countries, saw significant numbers of migrants arriving from Southern Europe but also from Central and Eastern Europe, a situation that continued until the late 1930s (Stengers 1993). For instance, the number of Polish citizens recruited to work in Belgian coalmines grew from 198 in 1922 to almost 12,000 in 1930 (Caestecker 1990). After World War II, the economic recovery fostered renewed immigration into Belgium through bilateral recruitment agreements with sending countries. The first agreement was signed between Belgium and Italy in June 1946 and secured the recruitment of thousands of Italian workers for the coal and steel industries. As a consequence, Italians quickly became the largest foreign population in Belgium (see Table 7.3).

The growing demand for labour and a dispute with the Italian government over the working conditions of Italian workers in the 1950s prompted the Belgian authorities to look elsewhere for labour. New agreements were thus signed with Spain, Greece, Turkey and Morocco during this period. As shown in census data, the number of immigrants residing in Belgium almost doubled between 1947 and 1970 and accounted for over $7 \%$ of the total population in the eve of the Oil Crisis. Although Italians still constituted the largest foreign group (35\% of the total immigrant population) in 1970, other Southern Europeans communities-such as Spaniard and Greeks-had grown significantly. In the meantime, the Cold War reduced dramati-

\footnotetext{
${ }^{3}$ The right to social aid scheme (DAS) is aimed at covering the basic needs of those sectors of the population that do not qualify for the right to social integration benefits (e.g. asylum seekers or foreigners who have the right to reside in Belgium but are not yet registered in the population registry).
} 


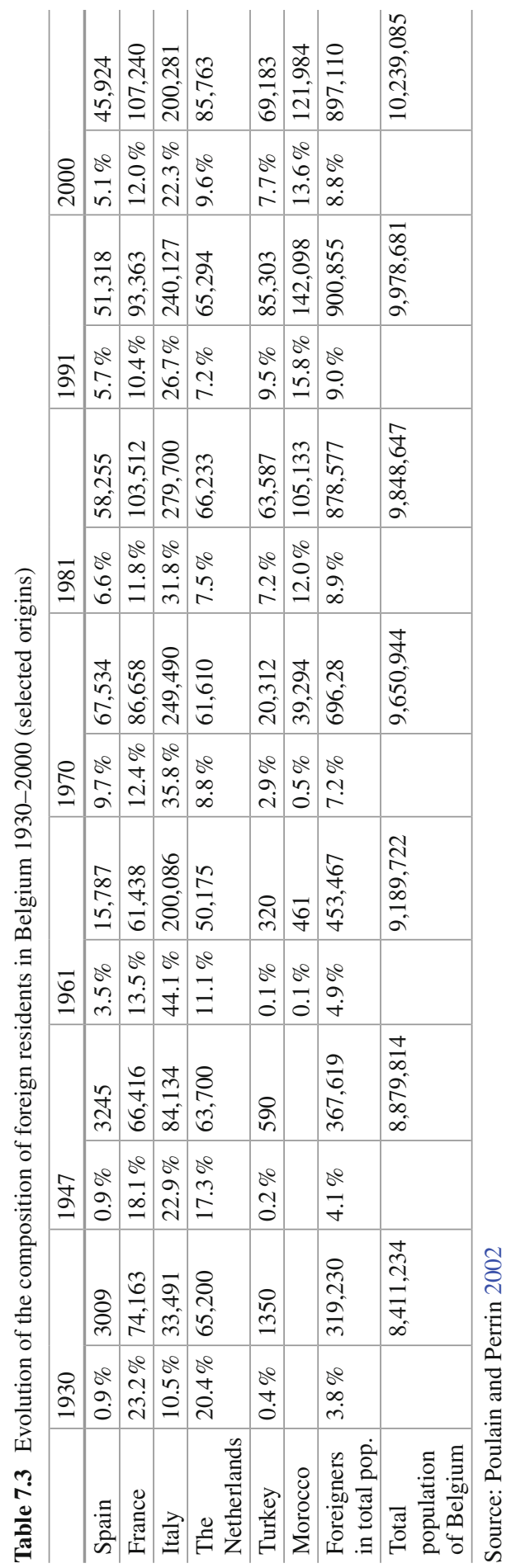


cally Central and Eastern European migration to Belgium. One last noteworthy feature of Belgium's post-war migration is that it explicitly allowed workers to come to the country with dependants in the hope that it would facilitate the workers' adaption to their new country while also addressing the country's demographic deficit (Bousetta et al. 2002).

This policy came to an end with the Oil Crisis and the government's decision in 1974 to cancel foreign worker recruitment programmes. However, this did not mean that migration stopped altogether. Indeed, the foreign resident population grew by almost 200,000 between 1970 and 1980 and their share of the total population reached $9 \%$. EU and third country migration to Belgium significantly transformed between the Oil Crisis and 2000. First, European migration to Belgium continued to intensify with the European integration process. In spite of the slowing down of the migration of Italian nationals, who had historically represented the largest European population in Belgium, growing immigration from neighbouring countries and from Central and Eastern Europe largely compensated for this. The consolidation of the role of Brussels as the capital of the EU, together with the growing needs for labour force_-in both high and low skilled occupations_-continued to attract EU citizens to Belgium. Overall, the percentage of EU migrants from neighbouring countries as part of the total foreign population increased, while that of Southern European migrants decreased. Second, family reunification schemes and relatively liberal asylum policies also increased the share of third country nationals in the total immigrant population during the same period.

\subsubsection{New Migration of Southern Europeans to Belgium: Flows and Stocks}

As discussed above, Belgium was not the EU Member State that was most affected by the financial and economic crisis. For this reason, it has remained a relatively attractive destination country since 2008. As shown in Table 7.4, the total yearly

Table 7.4 Migration flows in Belgium: inflows, outflows and net migration 2000-2012

\begin{tabular}{l|l|l|l}
\hline & Inflows & Outflows & Net migration \\
\hline 2005 & 97,888 & 44,298 & 53,590 \\
\hline 2006 & 101,872 & 45,573 & 56,299 \\
\hline 2007 & 109,926 & 45,437 & 64,489 \\
\hline 2008 & 126,069 & 52,407 & 73,662 \\
\hline 2009 & 126,877 & 57,873 & 69,004 \\
\hline 2010 & 140,375 & 55,468 & 84,907 \\
\hline 2011 & 138,071 & 58,000 & 80,071 \\
\hline 2012 & 125,000 & 70,357 & 55,000 \\
\hline
\end{tabular}

Source: RN-DGSIE 
inflow incremented from 93,345 to 138,071 between 2005 and 2011. Most of this increase was, however, due to recent EU enlargements to the East and the progressive removal by the Belgian authorities of the transition periods limiting the freedom of movement of citizens proceeding from those Member States. For instance, the absolute number of Polish migrants arriving in Belgium each year increased by almost 50\% from 6694 to 9851 between 2005 and 2011. Romanian migration also increased in a more dramatic fashion after the 2007 enlargement (from 3059 arrivals in 2006 to 11,784 in 2011).

Available data confirms that the deterioration of the economic situation in Southern EU countries has been a driving factor for the reactivation, after almost 40 years, of a new wave of migrants from this part of the continent. Although this flow is still comparatively less pronounced than migration from neighbouring countries and from Central and Eastern Europe, the number of new Southern Europeans arriving in Belgium is gradually increasing. As shown in Table 7.5, among Southern European countries, Spain is currently the nationality with the highest volume of inflow into Belgium. Arrivals of Spanish migrants nearly tripled from approximately 1900 in 2007 to over 5600 in 2011. In the case of Portuguese and Greeks migrants, the increase in arrivals has been significantly less intense when compared with the Spaniards and the Italians and, obviously, with nationals from new accession countries. In 2011, however, arrivals from Southern EU countries represented only $11 \%$ of the migration flows to Belgium.

The composition of the immigrant population by nationality has undergone considerable changes in recent years. Following the accession of Central and Eastern European countries, nationals from this area accounted for approximately $13 \%$ of the total population in 2013 (see Table 7.6). The stock of nationals from neighbouring countries, especially France and the Netherlands, has also increased steadily but its relative weight has remained unchanged $(30 \%)$. Similarly, despite the recent

Table 7.5 Immigration into Belgium by nationality 2005-2011

\begin{tabular}{l|l|l|l|l|l|l|l|l}
\hline & Nationality & 2005 & 2006 & 2007 & 2008 & 2009 & 2010 & 2011 \\
\hline 1 & France & 10,377 & 11,570 & 12,269 & 15,048 & 13,306 & 14,071 & 14,687 \\
\hline 2 & Romania & 2322 & 3059 & 5491 & 4222 & 3592 & 8447 & 11,784 \\
\hline 3 & $\begin{array}{l}\text { The } \\
\text { Netherlands }\end{array}$ & 10,109 & 11,488 & 11,370 & 12,321 & 9436 & 9654 & 10,198 \\
\hline 4 & Poland & 4815 & 6694 & 9393 & 9183 & 10,345 & 9121 & 9851 \\
\hline 5 & Morocco & 7106 & 7488 & 7831 & 8994 & 9957 & 10,360 & 9124 \\
\hline 6 & Spain & 1827 & 1848 & 1902 & 3095 & 3861 & 4795 & 5603 \\
\hline 7 & Italy & 2459 & 2613 & 2708 & 4499 & 4399 & 4747 & 5227 \\
\hline 8 & Bulgaria & 853 & 797 & 2625 & 7257 & 6568 & 4553 & 4740 \\
\hline 9 & Portugal & 1933 & 2030 & 2293 & 3541 & 3218 & 2910 & 3442 \\
\hline 10 & Turkey & 3389 & 2999 & 3180 & 3965 & 3852 & 3914 & 3265 \\
\hline$\ldots 17$ & Greece & 716 & 558 & 495 & 855 & 830 & 829 & 1201 \\
\hline & Others & 31,481 & 32,289 & 33,788 & 53,089 & 57,513 & 66,974 & 58,949 \\
\cline { 2 - 7 } & Total & 77,387 & 83,433 & 93,345 & 126,069 & 126,877 & 140,375 & 138,071 \\
\hline
\end{tabular}

Source: RN-DGSIE 


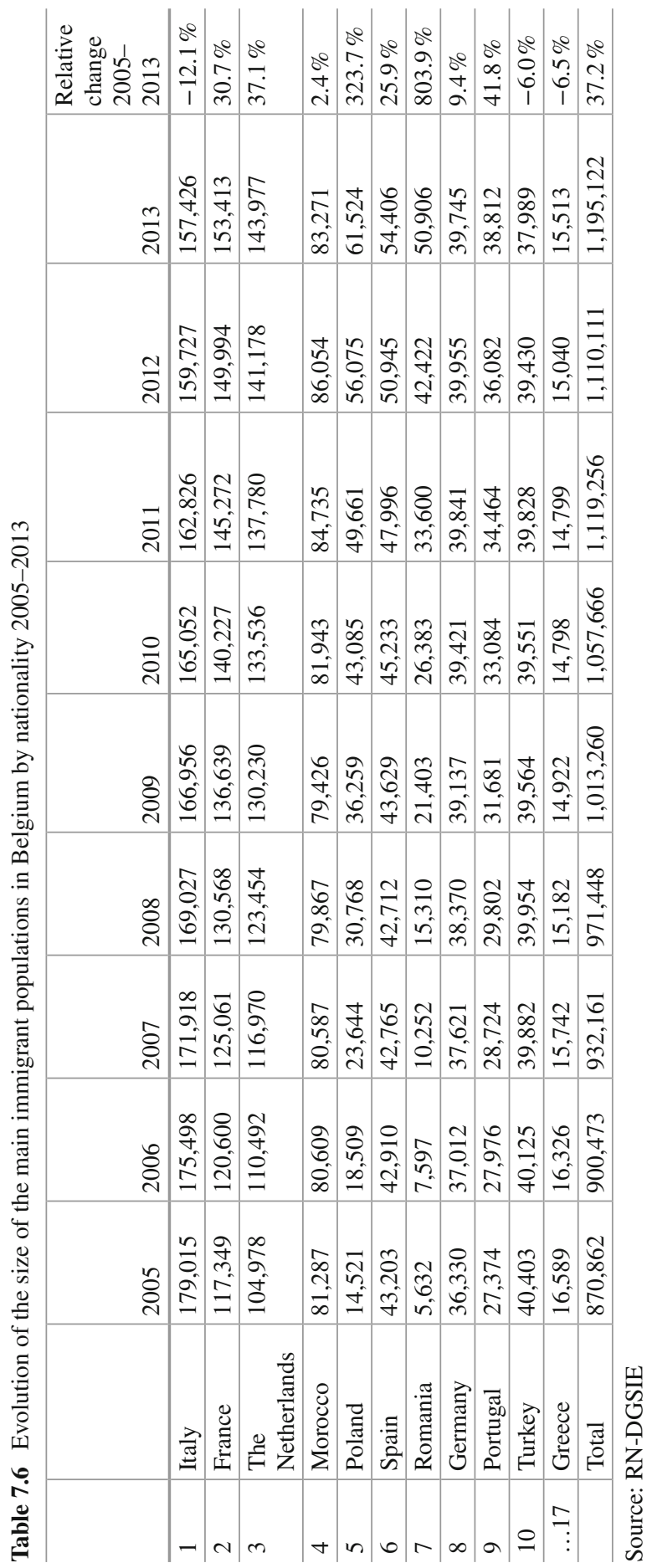


intensification of arrivals, the overall stock of nationals from Southern EU countries has not shown any growth. In 2005, the total number of Southern Europeans residing in Belgium was 266,181, while in 2014 it was 266,157. However, given the larger influx of migrants from Central and Eastern EU countries, the share of Southern Europeans in the total population diminished from $30 \%$ to $22 \%$. Italians and, to a much lesser extent, Greeks are two groups that decreased - respectively by 22,000 and 1000 individuals. This decline is directly related to the ageing of migrants that arrived in Belgium during the 1950s and 1960s economic boom, and this decline has not been halted by the arrival of new cohorts of migrants from Italy and Greece. By contrast, in the period under consideration, the Spanish and Portuguese populations increased by over 10,000 each. In these two cases, a longterm decrease has been reversed by the intensification of new arrivals since 2009 .

\subsubsection{Demographic and Socio-economic Characteristics of Southern European Migrants in Belgium}

As has been already stated, the demographic structure of the Southern European migration into Belgium is strongly conditioned by the past immigration of guest workers. Figure $7.2 \mathrm{a}-\mathrm{c}$ show the ageing demographic structure with a significant predominance of people over 45 years old. This corresponds to the cohorts of postwar guest workers. On the other hand, it can be observed that the age structure has been changing in recent years. The share of the oldest and the youngest age categories of Southern Europeans is gradually increasing. In the latter case, this is a result of the increasing inflow of new migrants after the outbreak of the crisis.

This duality in the age structure of the Southern European population contrasts with that of other large populations in Belgium. Nationals from the new accession members are concentrated in the categories of young adults and adults (24-44 years), which is consistent with the fact that this flow started relatively recently and is economically motivated. Migrants from neighbouring countries (France, Germany, Luxembourg and the Netherlands) show a relatively balanced age structure. This is due partly to the diversity of reasons motivating those migrants to move to Belgium (work, retirement, family migration, study and a change of tax domicile) and partly to the fact that flows from these countries have been consistent over time.

\subsubsection{Labour Market Situation and Access to Non-contributory Social Benefits}

The demographic structure of the Southern Europeans population is related to their socio-economic situation. According to Belgian Social Security statistics, in 2012, Southern Europeans had one of the lowest activity rates among all foreign-born 


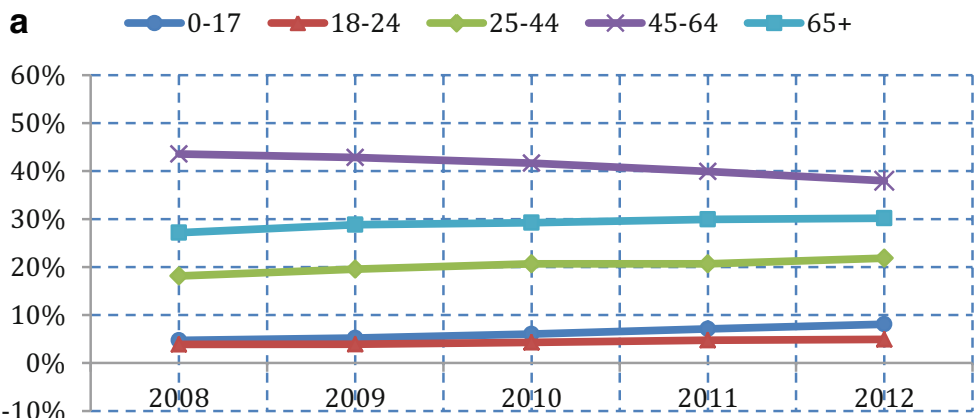

b

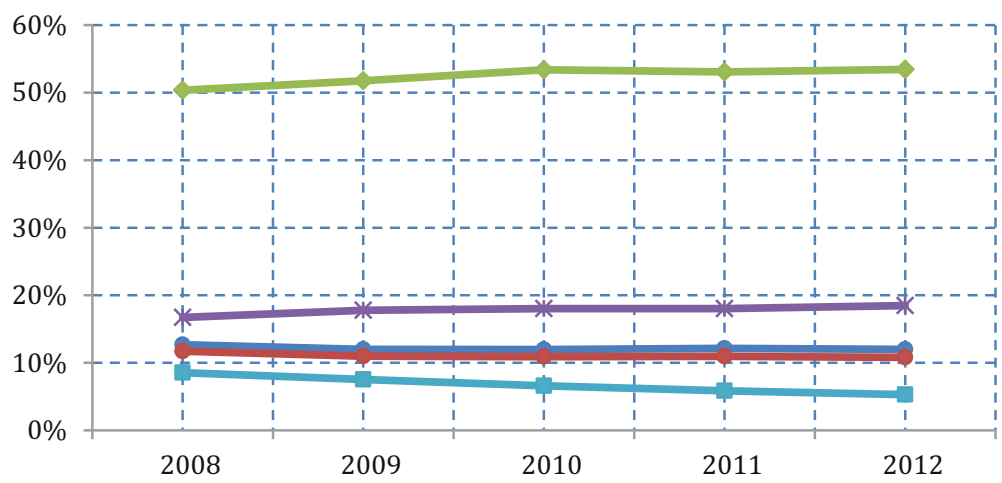

C

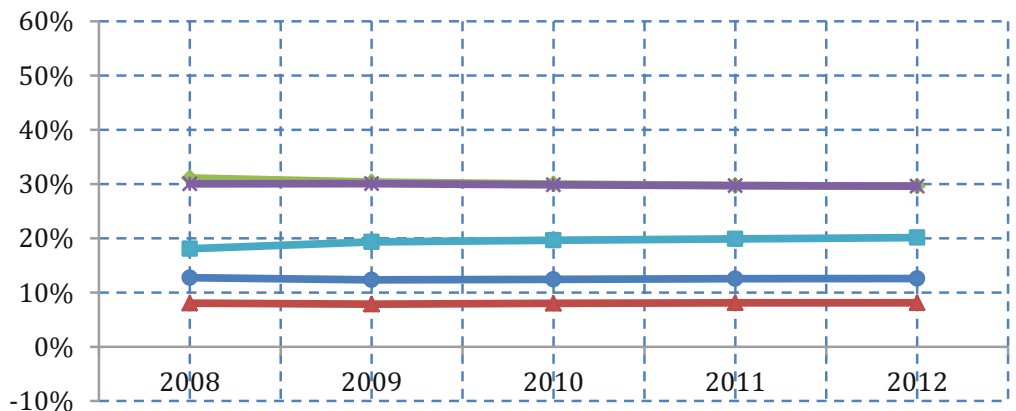

Fig. 7.2 Evolution of age composition from 2008 to 2012: (a) Southern Europeans*, (b) EU-12, (c) Neighbouring countries*** Greece, Italy, Portugal, Spain, **Bulgaria, Cyprus, Czech Republic, Estonia, Hungary, Lithuania, Latvia, Malta, Poland, Romania, Slovakia, Slovenia, ***France, Germany, Luxembourg, The Netherlands (Source: Banque Carrefour de la Sécurité Sociale 2008-2012) 
residents. This can be explained in good part by the age structure of this population. Indeed, if we focus specifically on the most economically active age categories (between 25 and 64), immigrants born in Southern EU countries are, along with migrants from the new accession countries, the most economically active population (see Table 7.7).

Yet, compared to migrants from other EU countries, Southern Europeans are also at higher risk of being unemployed. This phenomenon can be explained, on the one hand, by the obstacles faced by newcomers in the initial process of adjusting their skills to Belgian labour market needs. On the other hand, it is also possible that the new wave of Southern European migrants lacks the support structures and social networks that helped the incorporation of their predecessors into the labour market because of the considerable time gap between the old and the new migration waves (see discussion on this below).

Interestingly, the obstacles in the process of the labour market integration of new Southern European migrants have had no significant effect on their use of the Belgian non-contributory welfare system. As can be observed in Tables 7.8 and 7.9, Southern Europeans rely only to a modest degree on benefits provided by the social integration income (RIS) scheme, which is the main form of non-contributory social assistance in Belgium (see footnote 2). After initial increases in 2008 and 2009, the

Table 7.7 Activity and unemployment rates of foreign born populations by origin 2012

\begin{tabular}{l|l|l|l}
\hline & $\begin{array}{l}\text { Activity rate all } \\
\text { populations }\end{array}$ & $\begin{array}{l}\text { Activity rate age } \\
\text { group 25-64 }\end{array}$ & $\begin{array}{l}\text { Unemployment rate age } \\
\text { group 25-64 }\end{array}$ \\
\hline Southern EU & $33.5 \%$ & $63.5 \%$ & $12.9 \%$ \\
\hline EU-12 & $50.0 \%$ & $64.7 \%$ & $5.9 \%$ \\
\hline EU neighbour & $34.6 \%$ & $58.6 \%$ & $11.4 \%$ \\
\hline Other EU & $32.2 \%$ & $48.7 \%$ & $6.8 \%$ \\
\hline $\begin{array}{l}\text { Third country } \\
\text { nationals }\end{array}$ & $43.1 \%$ & $58.3 \%$ & $20.1 \%$ \\
\hline Belgium & $43.7 \%$ & $87.7 \%$ & $7.6 \%$ \\
\hline Total & $43.0 \%$ & $81.6 \%$ & $8.9 \%$ \\
\hline
\end{tabular}

Source: Banque Carrefour de la Sécurité Sociale

Table 7.8 Proportion of beneficiaries of the social integration income (RIS) scheme within each nationality

\begin{tabular}{l|l|l|l|l|l|l}
\hline & 2008 & 2009 & 2010 & 2011 & 2012 & 2013 \\
\hline Southern EU & $1.4 \%$ & $1.6 \%$ & $1.8 \%$ & $1.8 \%$ & $1.8 \%$ & $1.8 \%$ \\
\hline EU-12 & $3.1 \%$ & $3.9 \%$ & $4.6 \%$ & $4.2 \%$ & $3.5 \%$ & $3.0 \%$ \\
\hline EU neighbour & $1.6 \%$ & $1.7 \%$ & $1.8 \%$ & $1.7 \%$ & $1.5 \%$ & $1.5 \%$ \\
\hline Other EU & $0.6 \%$ & $0.7 \%$ & $0.8 \%$ & $0.7 \%$ & $0.6 \%$ & $0.6 \%$ \\
\hline Non-EU & $8.9 \%$ & $8.7 \%$ & $8.4 \%$ & $7.5 \%$ & $8.4 \%$ & $7.1 \%$ \\
\hline Belgium & $1.1 \%$ & $1.2 \%$ & $1.2 \%$ & $1.2 \%$ & $1.2 \%$ & $1.2 \%$ \\
\hline Total & $1.4 \%$ & $1.4 \%$ & $1.5 \%$ & $1.4 \%$ & $1.5 \%$ & $1.5 \%$ \\
\hline
\end{tabular}

Source: Intégration Sociale (2013) 
Table 7.9 Distribution of beneficiaries of the social integration income (RIS) scheme by nationality within the total population of Belgium

\begin{tabular}{l|l|l|l|l|l|l}
\hline & 2008 & 2009 & 2010 & 2011 & 2012 & 2013 \\
\hline Southern EU & $2.5 \%$ & $2.7 \%$ & $2.9 \%$ & $3.0 \%$ & $3.0 \%$ & $2.9 \%$ \\
\hline EU-12 & $1.4 \%$ & $2.0 \%$ & $2.8 \%$ & $3.1 \%$ & $3.0 \%$ & $2.9 \%$ \\
\hline EU neighbour & $3.3 \%$ & $3.5 \%$ & $3.5 \%$ & $3.4 \%$ & $3.2 \%$ & $3.1 \%$ \\
\hline Other EU & $0.2 \%$ & $0.2 \%$ & $0.2 \%$ & $0.2 \%$ & $0.2 \%$ & $0.1 \%$ \\
\hline Non-EU & $19.4 \%$ & $17.9 \%$ & $17.7 \%$ & $17.6 \%$ & $17.6 \%$ & $17.0 \%$ \\
\hline Belgium & $73.3 \%$ & $73.6 \%$ & $72.9 \%$ & $72.7 \%$ & $73.0 \%$ & $74.1 \%$ \\
\hline Total & $100.0 \%$ & $100.0 \%$ & $100.0 \%$ & $100.0 \%$ & $100.0 \%$ & $100.0 \%$ \\
\hline
\end{tabular}

Source: Intégration Sociale (2013)

share of beneficiaries of this scheme among Southern EU migrants has been constant and has not exceeded $2 \%$ of this population. It is, however, higher than the share of Belgians and migrants proceeding from neighbouring countries. On the other hand, the share of Southern Europeans who take up social benefits from the RIS scheme within the total population of Belgium has remained stable, at approximately $3 \%$. It remains to be seen, however, whether the limited use of noncontributory benefits by Southern EU migrants is related to the restrictions and controls implemented by the Belgian authorities against EU citizens in recent years (Mussche et al. 2013).

\subsection{Southern European Migrants in Belgium: From "Heroes" to "Welfare Shoppers"}

\subsubsection{EU Migrants in Belgium: Evolution of a Concept}

Large waves of immigration from Italy, and to a lesser extent from Spain, Portugal and Greece, durably marked Belgium's immigration history during the twentieth century. They have left visible traces until today in many neighbourhoods and many of these immigrants and their descendants now occupy visible positions in politics, trade unions, civil society organizations and academia. The most noticeable symbol of this process of socio-economic integration is the former Prime Minister Elio Di Rupo, the son of Italian immigrants who came to work in the Walloon coalmines in the 1940s. The visibility process led many observers to conclude that twentieth century Southern European immigration into Belgium had been a "success". In the past two decades, old Southern European migration flows to Belgium have thus been reinterpreted ex post as a desirable form of immigration in migration debates in Belgium. But how has this changed with the influx of new Southern European immigrants following the 2008 crisis?

As the origins of immigration into Belgium from Southern and Central and Eastern Europe predate the process of European integration, contemporary distinc- 
tions made between EU migrants and third country nationals have not always guided the country's immigration policies. As discussed in Part I, immigration into Belgium from border countries as well as from Italy and Poland finds its roots in the industrial development of Wallonia in the nineteenth century and it underwent its first acceleration after World War I. However, it was really after World War II that labour-intensive industries, such as coal and steel, stimulated demand for immigrant workers. The government thus developed a strategy of signing bilateral agreements first with Southern European countries and later with Morocco (1964), Turkey (1964), Tunisia (1969), Algeria (1970), and Yugoslavia (1970). At the time of the first bilateral agreement signed with Italy in 1946, the process of European integration had not yet started. The European Steel and Coal Community formed by Belgium, France, West Germany, Italy, the Netherlands and Luxembourg was, in fact, only founded in 1951. Similarly, when Belgium signed bilateral agreements with Spain (1956) and Greece (1957) in order to recruit workers, neither of these two countries was yet a member of the European Community. This means that early Southern European immigrants did not come to Belgium under Community provisions that would guarantee their freedom of circulation as workers. In other words, unlike today, the right of Southern European and North African immigrants to come to Belgium was guided by similar rules for most of the twentieth century.

This situation changed dramatically over time. The turning point came in 1968 with the end of visa requirements for EC migrants and the implementation of the right to look for employment without a work permit (Martiniello and Rea 2003). These differences in status between immigrants proceeding from EC countries (only Italians at the time) and other immigrants were further reinforced with the recession that started in the late 1960s. By then, the government had strictly reduced the issuance of new work permits, and on August 1, 1974, it officially put an end to 30 years of laissez-faire immigration policy by restricting entry only to immigrants whose skills were needed. In spite of this measure, the foreign population in Belgium continued to increase in the decades that followed through the granting of visas to skilled workers, the immigration of students, family reunification and the arrival of asylum seekers.

As the socio-economic conditions worsened in Belgium throughout the 1970s and 1980s, extreme-right parties began to build consistent electoral success on an anti-immigrant platform. By the early 1990s, the frontier between EC migrants and third country nationals was thus already very deep in Belgium. On the one hand, Italian and other Southern European migrants-as nationals of EC Member Statesenjoyed various employment, social and even political rights ensured by the treaties. On the other hand, immigrants and their descendants proceeding from other parts of the world did not enjoy the same level of protection and were most affected by rising unemployment and xenophobia.

In this declining socio-economic environment, which affected most particularly the industrial region of Wallonia, the legal differences between EC and non-EC migrants established by the treaties became progressively associated with normative judgements regarding these populations. More precisely, as xenophobia towards non-EC immigrants has risen, a process of idealization of old EU immigrants (and 
particularly of Italian immigrants) has taken place. In this sorting process between desirable and undesirable migrants, two dubious arguments are recurrently being used: the motivations behind migration and the "cultural distance" between migrants and natives.

Let us first address the argument regarding motivations behind migration. Since the 1980s, anti-immigration parties have supported the idea that - unlike their predecessors-new immigrants to Belgium do not come to work but to take advantage of the welfare system. One party in particular - the Flemish nationalist and xenophobic party Vlaams Blok (later renamed Vlaams Belang) — has played a key role in the dissemination of this idea. Following on from its initial major success in the 1987 legislative elections, running on an anti-immigration platform, the party formalized its stance through a 70-point programme in 1992. At the core of this programme, many measures proposed differentiated access to social security and unemployment benefits, as well as a different taxation system for EU and for nonEU migrants (Erk 2005). Rhetorical arguments regarding the cost that third country migrants supposedly represent to the Welfare State is historically based on immigration statistics describing the types of visa granted to third country nationals in order to gain access to the national territory. Recent data confirms that only a minority of third country nationals are granted residence permits for employment reasons $(7.6 \%$ in 2011), while family reasons (42.4\%), humanitarian reasons $(10.3 \%)$ and education $(6.7 \%)$ represent the bulk of registrations (UCL \& Centre pour l'égalité des chances 2013). This administrative data, however, exclusively reflects the modalities of access to the Belgian territory (e.g. family reunification, study, etc.) and not necessarily the intentions of migrants once they get there. In other words, the inability to obtain residence permits for employment reasons forces third country nationals to use other modalities to gain access to the employment market.

The second argument used to differentiate between new and old immigrants insists on the supposed inability of the new arrivals to integrate because their religious beliefs and cultural traits are too different from those of natives. Here too, the Vlaams Belang has repeatedly used this argument to target third country immigrants and their descendants (especially those proceeding from Maghreb and Turkey) (Meuleman and Billiet 2005). Depicting old Southern European immigrants as culturally closer to natives, however, contradicts historical accounts of the first decades of Italian presence in Belgium. As shown by Martiniello (1992) and Morelli (1988), Italian immigrants faced high levels of discrimination in Belgium after World War II and were, in fact, frequently accused of being too culturally different and too religious to integrate into Belgian society. Moreover, these scholars also showed that the high level of socio-economic integration of Italian migrants and their descendants must be related to other factors. The more favourable economic conditions in which these immigrants arrived and their ability to organize and occupy positions of power in trade unions and political parties are especially notable.

In spite of its lack of empirical foundations, this classification of immigrants into the categories of desirable post-war EU migrants and undesirable third country migrants has a strong performative value in Belgian politics. Over the years, classifying immigrants has been key to justifying selective migration and integration 
policies designed to continue to appeal to certain classes of foreigners. On the one hand, there are those that are considered to be both productive and able to integrate (e.g. highly-skilled workers, higher education students, wealthy EU citizens moving to Belgium for fiscal reasons, etc.), and public policies aim to attract these migrants into the country. On the other hand, there are the other groups that the policies aim to keep out (low-skilled immigrants, children and elderly citizens, asylum seekers, etc.). The reason for the spread of these ideas among Belgian policy-makers is to be found in the growing electoral success of the Vlaams Blok in Flanders. As shown by Koopmans et al. (2012), this party's success turned migration and integration into central political issues, so that other parties also felt compelled to pick up on these themes during their electoral campaigns (see also Coffé 2005; Adam and Torrekens forthcoming). It is certainly the case that Vlaams Blok's success never materialized in the form of government participation at the regional or federal level. Nevertheless, its ideas have been co-opted by other Flemish parties such as the right-wing nationalists of the New Flemish Alliance (N-VA) and the Liberal party (VLD), who have participated in several government coalitions since the late 1990s (Pauwels 2011).

With the accession of Central and Eastern European countries to the EU, the dichotomy between desirable and undesirable migrants has been applied for the first time within the category of EU migrants. In both 2004 and 2007, Belgium-along other Northern European Member States-implemented transitional measures to delay by 7 years the date at which workers from new EU Member States could enter freely into the Belgian job market. As of 1 January 2014, all restrictions have been lifted in relation to the mobility of EU-8 and EU-2 workers. Belgian political elites, however, continue to question the legitimacy of the arrival of these workers in Belgium. First, Central and Eastern European workers continue to be accused by the authorities of competing unfairly against Belgian workers. Second, the increased visibility of Central and Eastern European migrants in Belgian cities has led to increasing accusations of welfare shopping among new immigrants in Belgium. This latter consideration, in particular, has led the Government to develop new policies to control access to welfare in Belgium. A central policy that deserves further analysis in this respect is the removal of residence permits from EU citizens claiming benefits in Belgium. As we argue in the next section, this policy has led to increasing suspicion towards all EU migrants in Belgium and, in particular, towards new Southern European immigrants who left their country in the context of the economic crisis.

\subsubsection{Expelling EU citizens: The Limits of EU Citizenship in Belgium in Times of Crisis}

The belief among political elites that foreigners could be attracted to Belgium because of its welfare system is not new, but it has not always been considered to be a policy issue in the country. In fact, Belgium even advertised the advantages of its social system in Mediterranean countries after World War II, in order to persuade 
foreign workers to migrate to Belgium. It is thus only since the 1974 Oil Crisis and the subsequent decades of rising unemployment that foreigners have been increasingly depicted as a strain on the country's welfare system, in spite of a lack of evidence on the matter.

Over the years, the belief that welfare benefits are drivers of migration has guided several policy reforms that have affected both EU and third country nationals. In other words, restricting foreigners' access to social rights has progressively become a strategy to curb migration flows to Belgium. For instance, the idea that asylum seekers preferred Belgium over other destination countries because the benefits offered in Belgium were supposedly more generous than other countries led to the adoption of the 12 January 2007 Law on Asylum Seekers. This legislation strongly restricted the individual's ability to receive any cash-benefits during the asylum process.

Attempting to limit the immigration of EU citizens into Belgium through welfare provisions is, however, a much more complex matter, as the right to the mobility of workers and citizens has been enshrined in treaties and EU legislation over time. Nonetheless, looking at the number of EU citizens who have lost their right to reside in Belgium after claiming benefits in the country (Table 7.10), it can be argued that control on welfare use has effectively been turned into an instrument by which the Belgian authorities intend to keep undesirable EU migrants out.

As authorized by Directive 2004/38/EC on the right of citizens of the Union and their family members to move and reside freely within the territory of the Member States, Belgium started in 2011 to remove residence permits from EU citizens on the basis that they represent an "unreasonable burden on the social system" of the host country. Citizens targeted by this measure are not employees and the selfemployed but rather unemployed EU citizens. These EU citizens were originally granted residence permits in Belgium after they demonstrated that they possessed health coverage and sufficient resources to live autonomously. Nevertheless, because

Table 7.10 Number of residence permits removed by nationality on the basis of Directive 2004/38/EC

\begin{tabular}{l|l|l|l|l|l|l|l}
\hline & 2008 & 2009 & 2010 & 2011 & 2012 & 2013 & 2014 \\
\hline Spain & n/a & n/a & 75 & 98 & 207 & 323 & 245 \\
\hline Italy & n/a & n/a & 5 & 28 & 75 & 265 & 185 \\
\hline The Netherlands & n/a & n/a & 60 & 102 & 161 & 305 & 209 \\
\hline France & n/a & n/a & 21 & 32 & 109 & 176 & n/a \\
\hline Romania & n/a & n/a & 43 & 96 & 402 & 816 & 634 \\
\hline Slovakia & n/a & n/a & 91 & 108 & 73 & 60 & n/a \\
\hline Poland & n/a & n/a & 11 & n/a & 70 & 66 & n/a \\
\hline Bulgaria & n/a & n/a & 31 & 261 & 236 & 393 & 295 \\
\hline Other & n/a & n/a & 6 & 817 & 585 & 308 & 474 \\
\hline Total & 8 & 61 & 343 & 1542 & 1918 & 2712 & 2042 \\
\hline Change in $\%$ & - & $662,50 \%$ & $462,30 \%$ & $349,60 \%$ & $24,40 \%$ & $41,40 \%$ & $-24,70 \%$ \\
\hline
\end{tabular}

Sources: Office des Etrangers (2008, 2009, 2010, 2011, 2012, 2013) 
at some point after becoming official residents in Belgium, these immigrants received some form of social welfare, they began to be expelled. It is striking to note that the number of EU citizens expelled on this basis has increased exponentially between 2010 and 2013. Indeed, in 2011, the Minister for Social Integration De Block issued an executive order allowing an automatic exchange of information between the Social Security Administration and the Belgian Immigration Office. The consequence of this flow of information is visible in the sudden increase in the number of residence permits that were removed.

As documented in the press, many of these cases concerned citizens who applied for a living allowance or asked for social assistance because they faced a specific difficulty (e.g. unexpected hospital or utility bills). In other words, it is the category of EU citizens considered to be a burden that is being specifically targeted by this policy. Yet, the definition used by the administration to define social assistance is extremely lax. For instance, EU citizens hired under specific activation schemes financed by the Social Security Administration to work in schools or hospitals have equally faced expulsion. The rationale was that such publicly-financed jobs are not real jobs but rather a hidden form of assistance. The legality of such an interpretation has already been questioned in Belgium (Mormont and Neven 2014). Most importantly, however, the European Commission itself has expressed concerns over the sudden and dramatic increase in expulsions. It also reminded Belgium that it needed to pay more attention to the specific circumstances of each case, as expulsions should never be the automatic consequence of claiming benefits (European Commission 2014).

Looking at the nationality distribution of expelled EU citizens (Fig. 7.10), Romanians and Bulgarians have been the most affected by this policy. For these citizens, Belgium's policy to expel EU citizens who claim benefits is a continuation of previous policies that aimed to restrict their mobility into Belgium (e.g. through provisional measures that were only lifted on 1st January 2012). For this reason, the large-scale removal of residence permits among these nationals has failed to trigger a significant reaction from either Belgian civil society or the governments of these two countries of origin. The reaction has been very different towards the expulsion of nationals from old Member States, whose mobility into Belgium had never been a contentious issue (Dutch and French citizens) or whose mobility into Belgium had been idealized over the years (Italian, Spanish and Portuguese citizens).

Southern European migrants in particular have been most adamant in denouncing this new Belgian policy. During our fieldwork in Brussels, conducted between April 2013 and November 2015, we came across three examples that demonstrated this. First, the Brussels' chapter of the Spanish social movements $15 \mathrm{M}$ and Marea Granate (see Chap. 6) have organized numerous events in Brussels in order to shed light on the issue but also to raise awareness among new immigrants about the potential consequences of claiming social security benefits in Belgium. In November 2015, these movements also jointly submitted a petition to the European Parliament Committee on Petitions, asking Parliament to remind Belgium that the automatic nature of its expulsion policy does not respect Directive 2004/38/EC (Cuartopoder 10/11/15). Second, two other new associations created in Brussels by young Italian 
newcomers-Giovani Italiani Europa and La Comune del Belgio-have also organized numerous events to raise awareness about the difficulties of new Southern European immigrants. For instance, Giovani Italiani Europa organized two major conferences inside the European Parliament calling on European authorities to facilitate the mobility of young Europeans but also calling on the Italian government to adopt policies that will put an end to what they perceive as a new Italian brain drain. La Comune del Belgio, by contrast, adopted a more pragmatic approach by setting up jointly with a Belgian non-profit organization a free legal aid service. There, expelled EU citizens can receive advice on how to challenge the administrative decision that forces them to leave the country. Third, together with a series of Belgian non-profit organizations, the Italian Trade Union INCA-CGIL took the initiative to file a formal complaint to the European Commission regarding Belgium's widespread expulsion of EU citizens. The letter explicitly asked the Commission to initiate an infringement procedure against Belgium. Their hope is that this will force the country to abandon or revise a policy that these organizations consider to be a breach of Belgium's EU obligations (Osservatorio Inca 2014). The Commission responded favourably to this request and started to investigate the matter in June 2015.

Looking at these examples, it is striking to note that, despite being less affected numerically by the expulsions than other groups, Southern European immigrants have been the most vocal opponents of the policy. In fact, it is these immigrants who have managed to give the greatest visibility to the issue in the Belgian and European media and have managed to voice their concern in important forums such as the European Parliament. Similarly, Southern European migrants have set up the most elaborate legal responses to the policy using rights available at the Belgian and EU level. This situation can be explained by three factors. First, new Southern European immigration into the city of Brussels in particular consists partly of highly-educated migrants who come to Belgium in search of employment opportunities within the EU institutions and organizations that gravitate around them. It is thus not surprising that this particular kind of new migrant is more aware of his/her rights as a EU citizen but also more capable than others in catching the attention of the EU authorities and the international media in Brussels. Second, even though the members of these new Southern European organizations tend to underline the difficulty in connecting with co-nationals settled in Belgium for decades, new Italian immigrantsin particular - are able to benefit from an extensive network of Italian associations and institutions (trade unions, political parties, consulates, etc.), which have traditionally defended immigrant rights in Belgium. The support of the Brussels chapter of the Italian trade Union INCA-CGIL for the legal challenge against the Belgian government is very telling in this respect. Third, these new immigrant organizations are characterized by their strong transnational linkages with chapters of the same organizations in other destination countries or more simply with other immigrant organizations abroad. These linkages are an important resource when trying to challenge Belgium's policy at the supranational level: it gives them visibility in foreign media and contributes to exposing Belgium at the international level in the hope that it will change its policy. 


\subsection{Conclusions: Welfare Policies as Tools for Migration Control}

In this chapter, we have shown that Southern European Immigration into Belgium has increased since the beginning of the economic crisis. However, the arrival of these new immigrants failed to trigger perceptible fears among the population and policymakers. The perceived successful integration of previous immigration waves from Southern Europe has certainly facilitated the arrival of these new migrants in Belgium. At the same time, as a country characterized by a very open economy that also hosts several large international institutions, the number of high-skilled immigrants has also kept increasing at a steady rate over the last few years.

However, not all newcomers benefit from an equally positive perception in Belgium. The increasing presence of asylum seekers and EU citizens proceeding from Central and Eastern Europe has, by contrast, been received from a negative perspective, and specific policies have been designed in recent years to discourage these forms of migration. In particular, access to welfare has been increasingly described as a "pull factor" that attracts potential immigrants more interested in receiving benefits than in working. In this regard, the rhetoric of the former Secretary of State for Migration and Social Integration De Block has been crucial in depicting Belgium's social welfare as an overgenerous system that attracts undeserving immigrants. For this reason, she has made it a priority "to avoid immigrants coming here only to take advantage of the social system" (RTL info 2014).

However, this process of classification of immigrants as either desirable or undesirable largely precedes the crisis. Starting with the 1974 Oil Crisis and intensifying with the growing influence of the extreme-right party Vlaams Belang on Belgian politics, Belgium has made gaining access to its territory increasingly difficult for third country nationals, whilst still adhering fully to the principles of the freedom of circulation of workers and citizens within the European Union. This has led to a strong differentiation in legal status (and perception regarding the legitimacy of their presence) between EU and third country migrants, who had long been treated on an equal footing in Belgium until the middle of the twentieth century. The process of classification within the category of EU citizens is, however, a more recent phenomenon, whose implementation is rendered very difficult by the protection offered to mobile EU citizens by treaties and directives. The fear of a possible massive arrival of immigrants after the accession of Central and Eastern European countries to the EU in 2004 and 2007 pushed Belgium-along with other North-Western EU Member States - to restrict temporarily the freedom of circulation of those citizens described either as welfare shoppers or unfair competitors against Belgian workers. These restrictions have been progressively lifted, but the fear of invasion remains. Consequently, Belgium is now using other measures to keep undesirable EU citizens out, such as the intensification of controls on worksites where posted workers are traditionally employed.

With the economic crisis and the increasing pressure on public finance, this process of delegitimizing the presence of some EU citizens in Belgium has intensified. 
As Directive 2004/38/EC offers very little room for restricting the rights of mobile EU citizens, the control of EU citizens' use of welfare rights is increasingly being used as a means to restrict access to the territory only to working EU citizens who are not considered to compete unfairly with Belgian workers. Whereas this policy targets primarily Romanian and Bulgarian citizens, the presence of Spanish, Dutch, Italian and French citizens in the list of nationalities most affected by the removal of residence permits has triggered strong debates in Belgium. The visibility given to this strict policy by the Secretary of State to Migration De Block has only contributed to reinforce the cliché according to which immigrants move to Belgium to take advantage of its welfare system. In addition, it has extended this cliché to EU citizens whose presence in Belgium had never previously been questioned (the French and Dutch) or had even been considered as an example of successful integration within Belgium (Italians).

Previous occasions during which Roma migrants from Romania and Slovakia had been removed by the police from houses they illegally occupied had already confirmed that citizens from those Member States were considered undesirable in Belgium. To see French and Southern European citizens expelled on similar grounds as Romanians and Bulgarians, however, marked a key moment in Belgium's policy towards mobile EU citizens. By applying the strictest interpretation of Directive 2004/38/EC when it comes to "welfare abuse" by mobile EU citizens, Belgium clearly intends to set strict limits on the concept of EU citizenship through its social policy. Unlike other groups of new immigrants, Southern European migrants have mobilized more visibly and more formally against Belgium's policy. This greater ability to mobilize, we argue, is supported by the specific profile of the new Southern European immigrants, their transnational connections and their ability to connect with home and host country institutions and organizations that have defended immigrant rights for decades.

\section{References}

Bousetta, H., Jacobs, D., Kagné, B., Martiniello, M., Nys, M., Rea, A., et al. (2002). Multicultural policies and modes of citizenship in Belgium: The cases of Antwerp, Liège and Brussels. Brussels: IPSoM.

Caestecker, F. (1990). Le multiculturalisme de la Belgique: Une analyse de la politique de scolarisation des enfants polonais en Belgique 1923-1940. Belgisch Tijdschrift voor Nieuwste Geschiedenis, 21(3/4), 535-573.

Castanheira, M., Rihoux, B., \& Bandelow, N. C. (2014). 2014 Belgium report sustainable governance indicators 2014 project. Gütersloh: Bertelsmann Stiftung.

Coffé, H. (2005). The adaptation of the extreme right's discourse: The case of the Vlaams Blok. Ethical Perspectives: Journal of the European Ethics Network, 12(2), 205-230.

Cuarto Poder. (2015). Marea Granate y 15M Bruselas denuncian las expulsiones de españoles en la UE [Marron Wave and M15 report expulsions of Spaniard from the EU]. http://www.cuartopoder.es/invitados/2015/11/10/marea-granate-y-15m-bruselas-denuncian-las-expulsiones-deespanoles-en-la-ue/6333. Accessed 15 Nov 2015.

De Mulder, J., \& Druant, M. (2011). The Belgian labour market during and after the crisis. Economic Review, 1, 89-104. 
Erk, J. (2005). From Vlaams Blok to Vlaams Belang: The Belgian far-right renames itself. West European Politics, 28(3), 493-502.

European Commission. (2014). Libre circulation: La Commission demande à la Belgique de respecter les règles de l'UE (pp. 1-11). Brussels: European Commission.

Freedman, M. (2012). Changes in attitudes towards immigration: Evidence from the European debt crisis (European Forum at the Hebrew University, Jerusalem Working Paper, 115). Jerusalem: Hebrew University

Hijzen, A., \& Venn, D. (2011). The role of short-time work schemes during the 2008-09 recession (OECD Social, Employment and Migration Working Papers, Vol. No. 115). Paris: OECD Publishing.

Høj, J. (2013). Enhancing the inclusiveness of the labour market in Belgium (Economic Department Working Paper, 1009). Paris: OECD

Intégration Sociale. (2013). Bulletin statistique. Brussels: Intégration Sociale.

Koopmans, R., Michalowski, I., \& Waibel, S. (2012). Citizenship rights for immigrants: National political processes and cross-national convergence in Western Europe, 1980-2008. American Journal of Sociology, 117(4), 1202-1245.

La Libre Belgique. (2014, November 22). Theo Francken veut une immigration plus active. $L a$ libre Belgique, 4-5.

Martiniello, M. (1992). Leadership et pouvoir dans les communautés d'origine immigrée. Paris: L'Harmattan.

Martiniello, M., \& Rea, A. (2003). Belgium's immigration policy brings renewal and challenges (Country series). Washington, DC: Migration Policy Institute. http://www.migrationpolicy.org/ article/belgiums-immigration-policy-brings-renewal-and-challenges). Accessed 17 Nov 2015.

Meuleman, B., \& Billiet, J. (2005). Etnocentrisme in Vlaanderen: opmars of afname? De evolutie van de perceptie van etnische dreiging tussen 1991 en 2004 en de relatie met institutioneel vertrouwen (pp. 37-60). Brussels: Ministerie van de Vlaamse Gemeenschap.

Morelli, A. (1988). L'appel à la main d'oeuvre italienne pour les charbonnages et sa prise en charge à son arrivée en Belgique dans l'immédiat après-guerre. Revue Belge d'Histoire Contemporaine, XIX(1-2), 83-130.

Mormont, H., \& Neven, J.-F. (2014). Le droit à l'aide sociale et le droit à l'intégration sociale en faveur des étrangers: questions d'actualité. In J. Clesse \& J. Hubin (Eds.), Questions spéciales de droit social Hommage à Michel Dumont (pp. 13-110). Bruxelles: Larcier.

Mussche, N., Corluy, V., \& Marx, I. (2013). Migrant access to social security - policy and practice in Belgium. Study for the Belgian national contact point of the European Migration Network $(E M N)$. Brussles: European Commission/European Migration Network.

Nelson, K. (2011). Improving the efficiency of social protection. Peer review in social protection and social inclusion. Brussels: European Commission.

OECD. (2015). OECD economic surveys. Belgium February 2015. Paris: OECD Publishing.

Office des Etrangers. (2008). Rapports d'activités. Bruxelles: SPF Intérieur.

Office des Etrangers. (2009). Rapports d'activités. Bruxelles: SPF Intérieur.

Office des Etrangers. (2010). Rapports d'activités. Bruxelles: SPF Intérieur.

Office des Etrangers. (2011). Rapports d'activités. Bruxelles: SPF Intérieur.

Office des Etrangers. (2012). Rapports d'activités. Bruxelles: SPF Intérieur.

Office des Etrangers. (2013). Rapports d'activités. Bruxelles: SPF Intérieur.

Osservatorio Inca. (2014). Expulsions de citoyens européens de Belgique. Violation des articles 7 et 14 de la Directive 2004/38 sur le droit de séjour des citoyens UE et des articles 4 et 61 du Règlement $n^{\circ} 883 / 2004$ sur le coordination de la sécurité sociale. http://www.osservatorioinca. org/section/image/attach/Lettre_CE_2014_11_04.pdf. Accessed 16 Nov 2015.

Pauwels, T. (2011). Explaining the strange decline of the populist radical right Vlaams Belang in Belgium: The impact of permanent opposition. Acta Politica, 46(1), 60-82.

Pignal, S. (2012). Belgium aims to cut $€ 1$ bn from spending in 2012. Financial Times. http://www. ft.com/cms/s/0/a46fc5c6-3a10-11e1-a8dc-00144feabdc0.html\#axzz4D0b9jds9 
Poulain, M., \& Perrin, N. (2002). The demographic characteristics of immigrant populations in the Belgium. In The demographic characteristics of immigrant populations. Population studies, No. 38. Strasbourg: Council of Europe Publishing.

Rihoux, B., Dumont, P., De Winter, L., Deruette, S., \& Bol, D. (2011). Belgium. European Journal of Political Research, 50(7-8), 913-921. doi:10.1111/j.1475-6765.2011.02013.x.

RTL info. (2014). Maggie De Block: "Il faut éviter que des gens profitent de notre système social". http://www.rtl.be/info/belgique/politique/1053395/maggie-de-block-il-faut-eviter-que-des-gensprofitent-de-notre-systeme-social-video

Starke, P., Kaasch, A., \& van Hooren, F. (2011). Explaining the variety of social policy responses to economic crisis: How parties and welfare state structures interact (TranState Working Papers, Vol. 154). Hamburg: Leibniz Information Centre for Economics.

Stengers, J. (1993). De immigratie van 1830 tot 1914: cijfermateriaal. In A. Morelli (Ed.), Geschiedenis van het eigen volk. De vreemdeling in België van de prehistorie tot nu (pp. 103114). Leuven: Kritak.

UCL, \& Centre pour l'égalité des chances. (2013). Rapport statistique et démographique 2013. Migrations et populations issues de l'immigration en Belgique. Brussels: Centre pour l'égalité des chances.

Open Access This chapter is licensed under the terms of the Creative Commons AttributionNonCommercial 2.5 License (http://creativecommons.org/licenses/by-nc/2.5/), which permits any noncommercial use, sharing, adaptation, distribution and reproduction in any medium or format, as long as you give appropriate credit to the original author(s) and the source, provide a link to the Creative Commons license and indicate if changes were made.

The images or other third party material in this chapter are included in the chapter's Creative Commons license, unless indicated otherwise in a credit line to the material. If material is not included in the chapter's Creative Commons license and your intended use is not permitted by statutory regulation or exceeds the permitted use, you will need to obtain permission directly from the copyright holder.

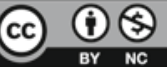

